\title{
KEADAAN HYGIENE SANITASI PADA PABRIK TAHU DI KELURAHAN PEGUYANGAN KECAMATAN DENPASAR UTARA TAHUN 2021 Studi dilakukan pada Pabrik Tahu Bapak Judin di Kelurahan Peguyangan Kecamatan Denpasar Utara
}

\section{Danka Alfariza Ayumi ${ }^{1}$, K Ketut Aryana ${ }^{2}$, M. Choirul Hadi ${ }^{3}$}

\begin{abstract}
Food is a basic human need, as a form of human rights for every society. So, the availability must be sufficient from the level of safety, quality, nutrition, and have a price that is affordable to the community. Good Food Production Method is one of the important factors to meet quality standards or food requirements. The research was conducted at a tofu factory owned by Mr. Judin in Peguyangan Village, North Denpasar District. In the industrial location there are 4 workers with problems with poor sanitation conditions. The purpose of this study was to determine the state of hygiene sanitation in the tofu factory by looking at the sorting of raw materials, storage of raw materials, processing of tofu, transportation of tofu and serving of tofu using observational descriptive methods. Sanitation hygiene assessment is divided into 2 categories that meet the requirements and do not meet the requirements by assessing the sorting of raw materials, storing raw materials, processing tofu and serving tofu, namely 2.6-5 and 0-2.5. From the observation results, the sorting of materials got a score of 5, storage of materials 3 , processing of tofu 3, transportation of tofu 1, serving of tofu 4. Selection of ingredients, storage of materials and presentation of materials had met the requirements. Processing and transportation do not meet the requirements. From the assessment, it meets the requirements. Must undergo repairs to complete sanitation hygiene components. Researchers suggest that managers and employees should carry out routine cleaning of the processing plant and production equipment used.
\end{abstract}

Keywords : Tofu factory, Condition of sanitation

\section{PENDAHULUAN}

Pangan merupakan kebutuhan manusia yang mendasar, sebagai bentuk hak asasi dari setiap masyarakat. Sehingga, dalam ketersediaannya harus mencukupi dari tingkat keamanan, mutu, gizi, dan memiliki harga yang terjangkau oleh masyarakat ${ }^{1}$.
Industri rumah merupakan industri yang hampir seluruh bahan bakunya berasal dari dalam negeri, dipasarkan dalam negeri, dan di konsumsi oleh masyarakat luas sehingga dapat memberi kontribusi terhadap ekonomi masyarakat kecil dan menengah ${ }^{2}$. Seperti 
industri pengolahan tahu yang merupakan industri kecil dan menengah rumah tangga dengan penghasilan limbah skala besar, baik dalam bentuk padat maupun cair jika tidak mendapatkan penanganan yang baik, maka akan berdampak pada lingkungan ${ }^{3}$. Berdasarkan data Dinas Kesehatan Provinsi Bali terdapat $47,1 \%$ TPM yang memenuhi syarat kesehatan. Hasil ini belum memenuhi target Renstra Kementerian Kesehatan tahun 2015 yaitu sebesar 75\%. Kabupaten dengan persentase tertinggi TPM yang memenuhi syarat kesehatan dan sudah memenuhi target yaitu sebesar 75\% adalah Badung (97,1\%), Jembrana $(89,7 \%)$ dan Buleleng (78,5\%). Sedangkan kabupaten dengan persentase terendah TPM yang memenuhi syarat kesehatan adalah Karangasem (15,7\%) diikuti oleh Gianyar $(22,1 \%)$ dan Kota Denpasar $(24,2 \%)^{4}$.

Tujuan penelitian ini untuk mengetahui keadaan hygiene sanitasi pabrik tahu dengan menilai pemilahan bahan baku, penyimpanan bahan baku, pengolahan tahu, pengangkutan tahu, dan penyajian tahu di Pabrik Tahu Bapak Judin Kelurahan Peguyangan Kecamatan Denpasar Utara.

\section{METODE PENELITIAN}

Jenis penelitian yang digunakan dalam penelitian ini yaitu dengan penelitian deskriptif yang bertujuan untuk melihat gambaran fenomena pada suatu populasi tertentu ${ }^{5}$. Penelitian ini dilaksanakan di Pabrik Tahu Bapak Judin di Kelurahan Peguyangan Kecamatan Denpasar Utara.

Populasi pada penelitian ini adalah sebuah Pabrik Tahu di Kelurahan Peguyangan Kecamatan Denpasar Utara. Data yang digunakan adalah data yang diperoleh dari hasil penilaian observasi keadaan hygiene dan sanitasi industri tahu. Penentuan kategori penilaian dilakukan dengan menggunakan rumus Sturgess.

$$
\text { Interval }=\frac{\text { skor terting } i-\text { skor terendah }}{\text { jumlah kelas }}
$$

Kategori pemilihan bahan, penyimpanan bahan, pengangkutan tahu, dan penyajian tahu mendapatkan skor tidak memenuhi syarat (0-2.5) memenuhi syarat (2.6-5) dan kategori pengolahan tahu mendapatkan skor tidak memenuhi syarat (0-3.5) memenuhi syarat (3.6-7). Data disajikan dalam bentuk tabel yang dinarasikan. 


\section{HASIL DAN PEMBAHASAN}

1. Hasil pemilihan bahan baku

\section{Tabel 1}

\section{Hasil Observasi Pemilahan Bahan}

\begin{tabular}{|c|c|c|c|}
\hline No & Item Penilaian & $\begin{array}{c}\mathrm{Ya} \\
(\mathrm{N}=1)\end{array}$ & $\begin{array}{l}\text { Tidak } \\
(\mathrm{N}=\mathbf{0})\end{array}$ \\
\hline 1 & $\begin{array}{l}\text { Kedelai dalam keadaan } \\
\text { segar }\end{array}$ & 1 & \\
\hline 2 & Kedelai tidak rusak & 1 & \\
\hline 3 & Kedelai tidak kotor & 1 & \\
\hline 4 & $\begin{array}{l}\text { Tidak menggunakan bahan } \\
\text { tambahan } \\
\text { pangan/pengawet }\end{array}$ & 1 & \\
\hline 5 & $\begin{array}{l}\text { Keadaan kemasan kedelai } \\
\text { baik/tidak rusak }\end{array}$ & 1 & \\
\hline & Jumlah Skor & 5 & 0 \\
\hline & $\%$ & $100 \%$ & $0 \%$ \\
\hline
\end{tabular}

Pemilihan bahan yang baik dapat dilakukan dengan memilih bahan yang bergizi, sehat, aman, tidak mengandung pewarna, menggunakan wadah yang besih, tidak rusak bentuk fisiknya, tidak tercemar baik secara fisik, kimia, maupun biologik ${ }^{6}$. Untuk mendapatkan hasil olahan yang baik juga dapat dilakukan dengan menghindari penggunaan bahan makanan dari sumber tidak jelas akibat kualitasnya yang tidak terjamin ${ }^{7}$.

Penelitian ini sejalan dengan penelitian Azizah (2018), dimana hasil dari keadaan bahan makanan yang mencapai syarat presentase $95,65 \%$ memenuhi syarat dimana keadaan bahan makanan ditemukan dalam keadaan baik dan segar terutama pada biji-bijian yang diharapkan dalam keadaan utuh, kering, penuh (tidak kopong/berlubang), tidak terdapat noda, jamur, atau kotoran lain pada permukaan biji, tidak berkecambah, serta hanya memiliki bau yang khas dari biji. Bahan baku makanan juga harus terlindungi dari berbagai jenis bahaya baik dalam bentuk kimia maupun pertumbuhan mikroorganisme pathogen serta pembentukan toksin pada saat perjalanan dan penyimpanan bahan baku ${ }^{9}$.

2. Hasil penyimpanan bahan baku

Tabel 2

Hasil Observasi Penyimpanan Bahan

\begin{tabular}{|c|c|c|c|}
\hline No & Item Penilaian & $\begin{array}{c}\mathbf{Y a} \\
(\mathbf{N}=\mathbf{1})\end{array}$ & $\begin{array}{l}\text { Tidak } \\
(\mathrm{N}=0)\end{array}$ \\
\hline 1 & $\begin{array}{l}\text { Gudang tempat } \\
\text { penyimpanan kedelai } \\
\text { bersih }\end{array}$ & & 0 \\
\hline 2 & $\begin{array}{l}\text { Kedelai yang disimpan } \\
\text { tidak rusak }\end{array}$ & 1 & \\
\hline 3 & $\begin{array}{l}\text { Kedelai disimpan yang } \\
\text { kering (tidak dekat } \\
\text { dengan } \\
\text { sumber/genangan air) }\end{array}$ & 1 & \\
\hline 4 & $\begin{array}{l}\text { Penyimpanan Kedelai } \\
\text { tidak ditumpuk } \\
\text { berlebihan }\end{array}$ & 1 & \\
\hline 5 & $\begin{array}{l}\text { Penyimpanan bahan } \\
\text { tidak menyentuh lantai }\end{array}$ & & 0 \\
\hline & Jumlah Skor & 3 & 2 \\
\hline & $\%$ & $60 \%$ & $40 \%$ \\
\hline
\end{tabular}
makanan jadi harus dilakukan terpisah, tempat penyimpananan makanan harus bersih dan terpelihara serta disimpan sesuai dengan aturan dan jenisnya ${ }^{10}$. Penyimpanan bahan makanan dibedakan antara bahan 
makanan yang kering dan basah serta rapat dari serangga dan tikus ${ }^{8}$. Tempat penyimpanan bahan makanan harus memiliki ruangan tersendiri dimana lantai harus bersih dan kedap air, memiliki dinding yang bersih dan atap yang tidak bocor, ventilasi yang cukup dan memiliki pintu yang kuat serta bebas dari serangga dan tikus.

3. Hasil pengolahan tahu

Tabel 3

Hasil Observasi Pengolahan Tahu

\begin{tabular}{|c|c|c|c|}
\hline No & Item Penilaian & $\begin{array}{c}\mathbf{Y a} \\
(\mathbf{N}=\mathbf{1})\end{array}$ & $\begin{array}{l}\text { Tidak } \\
(\mathrm{N}=0)\end{array}$ \\
\hline 1 & $\begin{array}{l}\text { Tempat pengolahan } \\
\text { bahan makanan bersih }\end{array}$ & & 0 \\
\hline 2 & $\begin{array}{l}\text { Pencucian kedelai } \\
\text { dilakukan menggunakan } \\
\text { air bersih dan mengalir }\end{array}$ & 1 & \\
\hline 3 & $\begin{array}{l}\text { Alat penggilingan dalam } \\
\text { keadaan bersih sebelum } \\
\text { digunakan }\end{array}$ & & 0 \\
\hline 4 & $\begin{array}{l}\text { Hasil gilingan ditampung } \\
\text { pada wadah bersih, bebas } \\
\text { karat dan kotoran }\end{array}$ & 1 & \\
\hline 5 & $\begin{array}{l}\text { Tangki perebusan dalam } \\
\text { keadaan bersih sebelum } \\
\text { digunakan }\end{array}$ & & 0 \\
\hline 6 & $\begin{array}{l}\text { Kain yang digunakan } \\
\text { untuk penyaringan dalam } \\
\text { keadaan bersih }\end{array}$ & 1 & \\
\hline 7 & $\begin{array}{l}\text { Alat pencetakan tahu } \\
\text { dalam keadaan bersih } \\
\text { sebelum digunakan }\end{array}$ & & 0 \\
\hline & Jumlah Skor & 3 & 4 \\
\hline & $\%$ & $43 \%$ & $57 \%$ \\
\hline & Pengolahan & & perlu \\
\hline \multicolumn{4}{|c|}{$\begin{array}{l}\text { memperhatikan tempat pengolahan karena } \\
\text { terjadi peranan yang sangat penting pada } \\
\text { dapur, maka dari itu kebersihan dapur dan }\end{array}$} \\
\hline
\end{tabular}

lingkungan sekitarnya harus selalu bersih dan terjaga ${ }^{11}$. Proses pengolahan makanan terutama keadaan sanitasi dapur memiliki lantai yang kedap air, kesediaan air yang memadai (tidak terkontaminasi cemaran bentuk fisik), alat yang digunakan dalam produksi selalu dibersihkan sebelum dan sesudah digunakan, kedap air, anti karat, memiliki permukaan mulus, tidak mudah rusak dan berubah warna, serta mudah kering ${ }^{8}$.

Penelitian ini sejalan dengan penelitian milik Ainezzahira (2019), dalam penelitiannya dinyatakan bahwa lantai dari industri tahu yang menjadi objek penelitian hanya terbuat dari bata yang disemen dan mengalami pengikisan yang menyebabkan lantai bangunan tidak rata dan dapat menimbulkan terjadinya genangan air, hal ini dapat mempengaruhi proses daripada produksi bahkan dapat menimbulkan terjadinya kecelakaan kerja. Bersamaan dengan wadah perebusan yang digunakan terbuat dari bata semen yang berbentuk kotak yang merupakan bahan yang halus, tidak menyerap air dan tidak berkarat tetapi karena penggunaannya yg terus menerus menyebabkan terjadinya pembentukan celah dan kerak yang timbul akibat pencucian yang tidak dilakukan dengan rutin dan bersih. 
4. Hasil Pengangkutan Tahu

\section{Tabel 4}

Hasil Observasi Pengangkutan Tahu

\begin{tabular}{|c|c|c|c|}
\hline No & Item Penilaian & $\begin{array}{c}\mathrm{Ya} \\
(\mathrm{N}=1)\end{array}$ & $\begin{array}{l}\text { Tidak } \\
(\mathrm{N}=0)\end{array}$ \\
\hline 1 & $\begin{array}{l}\text { Pengangkutan bahan } \\
\text { menggunakan } \\
\text { kendaraan khusus (troli) }\end{array}$ & & 0 \\
\hline 2 & $\begin{array}{l}\text { Wadah pengangkutan } \\
\text { tahu menggunakan } \\
\text { penutup }\end{array}$ & & 0 \\
\hline 3 & $\begin{array}{l}\text { Wadah pengangkut tahu } \\
\text { jadi harus bersih }\end{array}$ & & 0 \\
\hline 4 & $\begin{array}{l}\text { Wadah pengangkutan } \\
\text { tahu yang sudah jadi } \\
\text { kuat }\end{array}$ & 1 & \\
\hline 5 & $\begin{array}{l}\text { Wadah pengangkut tahu } \\
\text { yang sudah jadi tidak } \\
\text { rusak }\end{array}$ & & 0 \\
\hline & Jumlah Skor & 1 & 4 \\
\hline & $\%$ & $20 \%$ & $80 \%$ \\
\hline
\end{tabular}

berperan penting dalam mencegah terjadinya kontaminasi pada makanan dimana banyaknya pihak yang berkaitan dalam proses persiapan hingga alat pengangkut yang digunakan dalam pengambilan bahan atau makanan dalam jarak dekat biasanya digunakan tray dan apabila dalam jumlah berlebih dapat menggunakan troli khusus makanan $^{13}$. Penelitian ini sejalan dengan penelitian milik Ainezzahira (2019) dimana peralatan produksi yang digunakan belum sesuai dengan persyaratan karena alat yang digunakan langsung bersentuhan dengan tanah yang memungkinkan terjadinya kontaminasi.
5. Hasil penyajian tahu

Tabel 5

Hasil Observasi Penyajian Tahu

\begin{tabular}{|c|c|c|c|}
\hline No & Item Penilaian & $\begin{array}{c}\mathrm{Ya} \\
(\mathrm{N}=1)\end{array}$ & $\begin{array}{l}\text { Tidak } \\
(\mathrm{N}=\mathbf{0})\end{array}$ \\
\hline 1 & $\begin{array}{l}\text { Wadah tahu yang sudah } \\
\text { jadi bersih (tidak } \\
\text { berjamur/kotor) }\end{array}$ & 1 & \\
\hline 2 & $\begin{array}{l}\text { Wadah tahu yang sudah } \\
\text { jadi memiliki penutup }\end{array}$ & 1 & \\
\hline 3 & $\begin{array}{l}\text { Wadah tahu yang sudah } \\
\text { jadi utuh/tidak rusak }\end{array}$ & 1 & \\
\hline 4 & $\begin{array}{l}\text { Wadah pengangkutan } \\
\text { tahu yang sudah jadi kuat }\end{array}$ & 1 & \\
\hline 5 & $\begin{array}{l}\text { Tahu yang sudah jadi } \\
\text { tidak disajikan kontak } \\
\text { langsung dengan tangan }\end{array}$ & & 0 \\
\hline & Jumlah Skor & 4 & 1 \\
\hline & $\%$ & $80 \%$ & $20 \%$ \\
\hline
\end{tabular}

sebaiknya dikemas dengan menggunakan

alat khusus sehingga makanan tidak mengalami kontak langsung dengan $\operatorname{tangan}^{14}$. Makanan sebaiknya disajikan pada tempat yang bersih, memiliki sirkulasi udara yang baik, penjamah berpakaian bersih, rapi, dengan celemek dan penutup kepala serta tidak adanya kontak langsung dengan makanan yang disajikan ${ }^{13}$. 
6. Keadaan hygiene sanitasi pabrik tahu

Tabel 6

Keadaan Hygiene Sanitasi Pabrik Tahu

\begin{tabular}{clcccc}
\hline \multirow{2}{*}{ No } & $\begin{array}{c}\text { Penilaian Hygiene } \\
\text { Sanitasi }\end{array}$ & \multicolumn{4}{c}{$\begin{array}{c}\text { Hasil Penilaian Hygiene } \\
\text { Sanitasi }\end{array}$} \\
\cline { 3 - 6 } & \multicolumn{1}{c}{ Ya } & $\%$ & Tidak & $\%$ \\
\hline 1 & $\begin{array}{l}\text { Pemilahan bahan } \\
\text { baku }\end{array}$ & 5 & $100 \%$ & 0 & $0 \%$ \\
2 & $\begin{array}{l}\text { Penyimpanan bahan } \\
\text { baku }\end{array}$ & 3 & $60 \%$ & 2 & $40 \%$ \\
3 & Pengolahan tahu & 3 & $43 \%$ & 4 & $57 \%$ \\
4 & Pengangkutan tahu & 1 & $20 \%$ & 4 & $80 \%$ \\
5 & Penyajian tahu & 4 & $80 \%$ & 1 & $20 \%$ \\
\hline
\end{tabular}

Hal-hal yang harus lebih diperhatikan terutama pada pengolahan dan pengangkutan daripada tahu pada saat produksi berlangsung. Melihat industri tahu sendiri kebanyakan merupakan industri kecil rumah tangga dengan teknologi yang sederhana serta memiliki sistem produksi yang berkelanjutan secara terus menerus dimana kebersihan dari alat, keadaan bangunan produksi, keutuhan daripada alat, dan keamanan pada saat produksi sangat jarang menjadi perhatian lebih.

\section{SIMPULAN DAN SARAN}

Berdasarkan penelitian yang telah dilakukan, hasil penelitian hygiene sanitasi pabrik tahu Bapak Judin disimpulkan sebagai berikut:

1. Pemilahan bahan baku mendapatkan skor 5 dan $(100 \%)$ sudah memenuhi syarat.

2. Penyimpanan bahan baku dengan skor 3 $(60 \%)$ memenuhi syarat.

3. Sanitasi pengolahan tahu dari segi persyaratan baru terpenuhi sebanyak 3 penilaian (43\%), pabrik tahu belum memenuhi syarat.

4. Keadaan sanitasi pengangkutan tahu baru terpenuhi 1 (20\%) dari persyaratan., pabrik tahu belum memenuhi syarat.

5. Penyajian tahu sudah terpenuhi sebanyak 4 penilaian (80\%) memenuhi syarat.

Saran yang dapat disampaikan, Bagi pemilik sebaiknya dapat menyediakan tempat penyimpanan yang lebih baik dengan ruangan tersendiri dan tertutup, menyediakan alas yang aman untuk menempatkan kedelai, melakukan pembaharuan alat yang telah rusak untuk keamanan jangka panjang pembuatan tahu, mengikuti pelatihan terkait hygiene sanitasi dan keamanan produksi pangan. Kepada karyawan selalu melakukan pembersihan rutin terhadap tempat pengolahan tahu dan 
penyimpanan kedelai, mencuci bersih alat yang telah digunakan dan memastikan tidak terdapat kerak yang tertinggal pada alat produksi agar tidak menimbulkan bakteri pathogen yang dapat berpengaruh pada tahu dengan menggunakan deterjen yang aman untuk alat dan makanan, mengikuti pelatihan dan mendapatkan edukasi terkait hygiene sanitasi dan cara produksi pangan yang baik.

\section{DAFTAR PUSTAKA}

1. Triyanni, T. R., Purwanggono, B. \& Pujitomo, D. Analisis Persiapan Penerapan Sistem Manajemen Hazard Analysis Critical Control Point (HACCP) Dan Penyusunan Rencana HACCP Pada Industri Pembuatan Tahu. Ind. Eng. Online J. 6, 1-8 (2017).

2. Kadriah, A., Hukum, F. \& Pamulang, U. Produk Hukum Sertifikasi Hygiene Sanitasi Usaha Berbasisi Industri Rumah Tangga Sebagai Upaya Peningkatan Nilai Usaha. J. Ilmu Huk. 1, (2018).

3. Jaya, J., Ariyani dan Hadijah Jurusan Teknologi Industri Pertanian, L., Negeri Tanah Laut Jl Yani Km, P. a, Laut, T. \& Selatan, K. Perencanaan Produksi Bersih Industri Pengolahan Tahu Di Ud. Sumber Urip Pelaihari Designing Clean Production of Tofu Processing Industry in Ud. Sumber Urip Pelaihari. Agroindustri 8, 105-112 (2018).

4. Dinkes. Profil Kesehatan Provinsi Bali Tahun 2015. (2015).

5. Prof. Dr. Soekidjo Notoatmodjo, S.K.M., M. C. H. Metodologi Penelitian Kesehatan. (Rineka Cipta, 2018).

6. Sari, Nurmala, Irnawati, M. \& Chahaya, I. Higiene Sanitasi Pengelolaan Makanan Dan Perilaku Penjamah Makanan Di Kantin Sekolah Menengah Atas (Sma) Negeri Dan Swasta Di Kecamatan Rantau Utara Kabupaten Labuhan Batu Tahun 2012. 78-101 (2012).

7. Mercy A. Lumare ${ }^{1}$, dan I. N. R. Kebersihan (Hygiene) Makanan dan Sanitasi di Rumah Makan Kampus. 8, 87-91 (2016).

8. Azizah. DESKRIPTIF HYGIENE SANITASI PENGELOLAAN MAKANAN DI LEMBAGA PEMASYARAKATAN KELAS IIB KABUPATEN CILACAP TAHUN 2017. 37, 475-481 (2018).

9. Sri Rejeki. Sanitasi Hygiene dan K3. (Rekayasa Sains, 2015).

10. Simbolon. Program studi s1 kesehatan masyarakat fakultas kesehatan masyarakat universitas sumatera utara 2019. (2019). 
11. I Ketut Bagiastra \& Si Luh Putu Damayanti. HYGIENE DAN SANITASI PEDAGANG SATE BULAYAG DI KAWASAN WISATA SURANADI TAHUN 2017. Director 15, 6-13 (2018).

12. Ainezzahira. VITKA Jurnal Manajemen Pariwisata. 1, 5-12 (2019).

13. Rahmadhani. Gambaran Penerapan Prinsip Higiene Sanitasi Makanan Di PT Aerofood Indonesia, Tangerang, Banten The Description of Food
Sanitation and Hygiene At PT Aerofood Indonesia , Tangerang , Banten. 291299

doi:10.20473/amnt.v1.i4.2017.291-299.

14. Fajriansyah. KONDISI INDUSTRI TAHU BERDASARKAN HYGIENE DAN SANITASI DI KOTA BANDA ACEH ( The Tofu industry condition based on hygiene and sanitation in the city of Banda Aceh ). Aceh Nutr. J. 2, 149-154 (2017). 